\title{
Hallazgos artroscópicos en un caso de disco articular adherido de la ATM
}

\section{Arthroscopic findings in a fixed disc case of the TMJ}

\section{R. Martín-Granizo López', J. Giner Díaz², J.J. Sánchez Gutiérrez}

Resumen: El síndrome de disco adherido (SDA) o stuck syndrome de la articulación temporomandibular (ATM) es un fenómeno que ha sido descrito recientemente y cuya fisiopatogenia es una alteración bioquímica que se produce en algunas ATMs con disfunción temporomandibular.

En el presente artículo describimos un caso clínico y especialmente los interesantes hallazgos artroscópicos encontrados, que ayudarían a corroborar el mecanismo fisiopatogénico propuesto. Son de especial relevancia la correcta posición discal dentro de la articulación y una zona eritematosa encontrada en la sinovial que recubre la fosa-eminencia glenoidea de la articulación.

Palabras clave: Síndrome de disco adherido; Stuck syndrome; Articulación temporomandibular.

Recibido: 20.10 .05

Aceptado: 29.11 .05

\begin{abstract}
The anchored disc phenomenon (ADP) or 'stuck syndrome' of the TMJ is a phenomenon that has only recently been described, with a physiopathogeny of biochemical disturbances that are produced in some TM/s with temporomandibular dysfunction. In this article we describe a clinical case and, in particular, the interesting arthroscopic findings that help to corroborate the physiopathogenic mechanisms proposed. Of special relevance is the correct position of the disc within the joint and an erythematous area found in the synovial membrane covering the glenoid fossa-eminence of the joint.
\end{abstract}

Key words: Anchored disc phenomenon; Stuck syndrome; Temporomandibular joint.

\footnotetext{
1 Médico Adjunto.

2 Médico Residente.

Servicio de Cirugía Oral y Maxilofacial (Jefe de Servicio: Dr. A Berguer).

Hospital Clínico San Carlos. Madrid, España.
}

\section{Correspondencia:}

Rafael Martín-Granizo López

C/ Guzmán el Bueno, 70, 4ª

28015, Madrid, España.

E-mail: rmartin.hcsc@salud.madrid.org 


\section{Introducción}

El síndrome de disco adherido (SDA) fue inicialmente descrito por la Dra. Dorrit Nitzan en el año 1991, como una posible causa de limitación brusca de la apertura de la boca.1,2 Posteriormente, ella misma estudió el proceso de lubrificación dentro de la articulación temporomandibular (ATM) basándose en la experiencia en cirugía ortopédica, ${ }^{3}$ y finalmente lanzó la hipótesis patogénica de este síndrome. ${ }^{4}$ El SDA (anchored disc phenomenon), también ha sido denominado como síndrome de disco anclado o stuck syndrome. Algunos autores lo incluyen dentro de las variantes del síndrome de disfunción temporomandibular (SDTM), siendo una de las causas de bloqueo articular (closed lock). ${ }^{5}$

Clínicamente, el SDA se manifiesta por una limitación generalmente brusca de la apertura oral y del movimiento de laterotrusión hacia el lado contralateral acompañados de dolor cuando se fuerza la apertura, con un end-feel duro. El diagnóstico de sospecha ha de confirmarse mediante un estudio con RM, en el cual característicamente se observará un disco inmóvil durante los movimientos de apertura y cierre de la boca. El tratamiento que tradicionalmente se ha propuesto consiste en algún tipo de procedimiento de cirugía mínimamente invasiva, bien artrocentesis o bien artroscopia. ${ }^{5}$

El objetivo del presente artículo es mostrar algunos hallazgos artroscópicos curiosos que no han sido previamente descritos, encontrados en un caso clínico de SDA.

\section{Caso clínico}

Mujer de 37 años de edad que acudió a nuestras consultas derivada desde otro Centro por dolor en ambas articulaciones temporomandibulares desde hacía años. Refería haber realizado diversos tratamientos conservadores que no habían sido efectivos. Era portadora de una férula oclusal tipo Michigan desde hacía 1 año que le había producido una ligera mejoría. Refería que hace 4 meses sufrió un episodio súbito de limitación de la apertura de la boca acompañado de una aumento del dolor en la ATM izquierda y que desde entonces no había podido colocarse la férula. Ante la pregunta de si escucha ruidos articulares, comenta que hasta esa fecha oía chasquidos en ambas articulaciones al abrir y cerrar la boca, pero que a partir de ese episodio dejó de escucharlos. Había tenido otros episodios de bloqueos que se habían resuelto espontáneamente. A la exploración se objetivaba una limitación de la apertura oral a $20 \mathrm{~mm}$ con una laterodesviación mandibular a la izquierda de $2 \mathrm{~mm}$. Las láterotrusiones eran de $5 \mathrm{~mm}$ a la izquierda y 1 $\mathrm{mm}$ a la derecha. La ATM izquierda era dolorosa a la palpación y la prueba de carga era positiva en el lado izquierdo. El end-feel era fijo e incrementaba el dolor en la ATM izquierda. El juicio clínico inicial fue de bloqueo discal (closed lock) en la ATM izquierda.

Se solicitaron unas pruebas de imagen. Así, la ortopantomografía (OPG) no mostró alteraciones óseas reseñables con unos cóndilos simétricos no deformes aunque pequeños. Las secuencias potenciadas en T1 de la RM de ambas ATMs en proyección sagital y coronal, en boca cerrada y en máxima apertura, evidenciaron

\section{Introduction}

The anchored disc phenomenon (ADP) was first described by Dr. Dorrit Nitzan in 1991 as a possible causative factor of a sudden restriction in mouth opening. ${ }^{1,2}$ Later, she herself studied the lubrication process within the temporomandibular joint (TMJ) based on her experience in orthopedic surgery, ${ }^{3}$ and she finally put forward the pathogenic hypothesis behind this syndrome. ${ }^{4}$ The anchored disc phenomenon has also been termed stuck syndrome. Some authors include it within the variants of the temporomandibular dysfunction syndrome (TMDs), and one of the causative factors of closed lock. ${ }^{5}$

Clinically, ADP manifests as a limitation in mouth opening and laterotrusion towards the contralateral side. It is generally sudden, accompanied by pain on forcing the mouth open, and the end-feel is hard. The suspected diagnosis has to be confirmed by means of a MR imaging study, which typically shows a static disc during opening and closing of the mouth. The treatment traditionally proposed consists in a type of minimally invasive surgery, either arthrocentesis or arthroscopy. ${ }^{5}$

The objective of this article is to show some unusual arthroscopic findings that have not been described previously and that were discovered in a clinical case with ADP.

\section{Clinical Report}

A 37-year-old female was referred to our department from another center complaining of pain in both temporomandibular joints that had been evolving for several years. She stated that she had undergone various types of conservative treatment, but that these had been unsuccessful. For a year she had been using a Michigan-type splint that had led to some improvement. She stated that four months previously she had suffered a sudden restriction in mouth opening, together with an increase in pain in the left TMJ, and that from that point she had been unable to use the splint. On being asked if she heard joint noise she said that up until then she had heard a clicking in both joints on opening and closing her mouth, but that this had since stopped. There had been other blocking incidences but these had resolved spontaneously. An oral aperture limitation of $20 \mathrm{~mm}$ was observed on examination, together with mandibular laterodeviation to the left side of $2 \mathrm{~mm}$. The laterotrusions were of $5 \mathrm{~mm}$ to the left side and $1 \mathrm{~mm}$ towards the right side. The left TMJ was painful to palpation and load bearing was positive on the left side. The end-feel was hard, with increased pain in the left TMJ. The initial clinical judgment was of closed lock of left TMJ.

Imaging test were requested. The OPG did not reveal any relevant bone alterations, and the condyles were undeformed and symmetric, although small. The T1 weighted $M R$ sequence showed both TM/s in sagittal and coronal views 
un desplazamiento discal anteromedial sin recaptura a la apertura de la boca en la ATM izquierda (Fig. 1) y un disco adherido o anclado en la ATM derecha (Fig. 2). Las secuencias T2 mostraban un derrame intraarticular en la ATM izquierda. Así pues, el diagnóstico final fue de luxación discal sin reducción en la ATM izquierda y síndrome de disco adherido en la ATM derecha.

Con este diagnóstico se planteó realizar una cirugía artroscópica para diagnosticar y tratar esta patología. Fue intervenida bajo anestesia general e intubación nasotraqueal y preparada según el protocolo habitual. Se utilizó un artroscopio tipo Dyonics HD 900 (Smith \& Nephew Inc., TARMA S.A.) con una lente de 1,9 mm de diámetro y $30^{\circ}$ de ángulo de visión y una fuente de luz de xenon. La intervención fue grabada en un video U-matic (Sony VO5630) y se capturaron e imprimieron imágenes mediante un video-printer (Sony Color Video Printer, Mavigraph UP-3000P). Se comenzó por la ATM derecha abordando el espacio articular superior empleando una vía pósterolateral estándar y una vía intermedia para la salida de suero. La exploración se llevó a cabo mediante el protocolo habitual, de posterior a anterior $y$ de lateral a medial, observando inicialmente una articulación casi normal sin sinovitis y con escasa inflamación de la
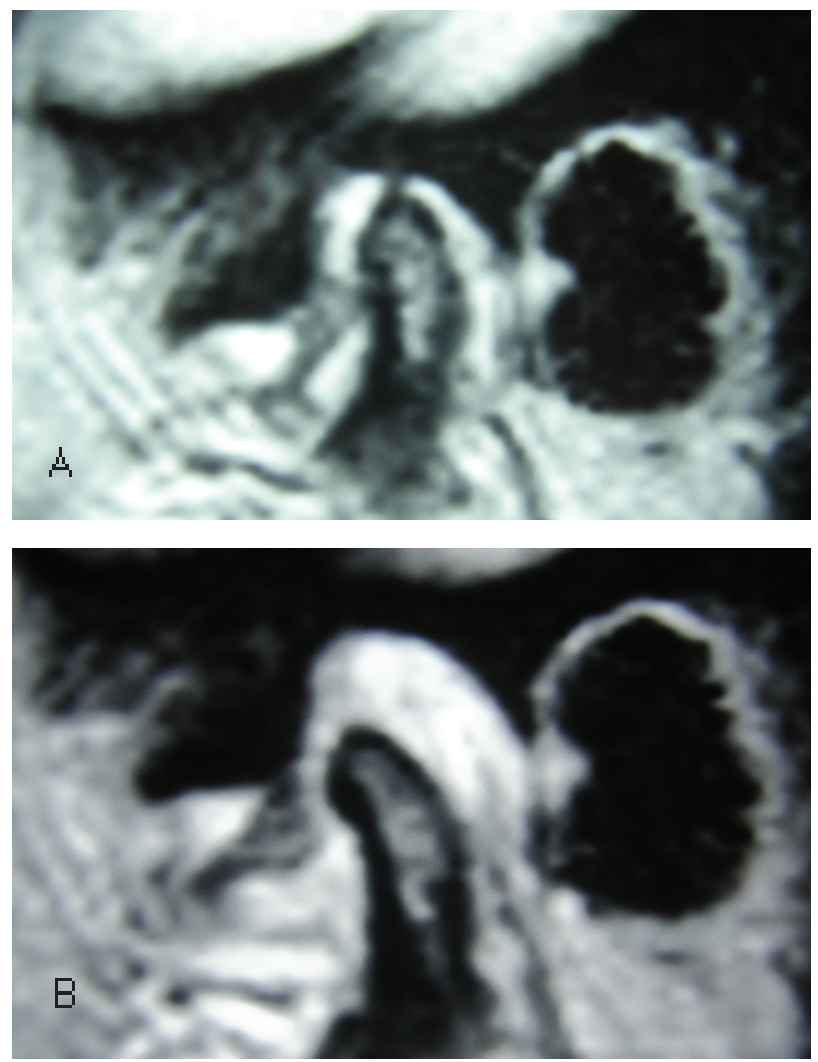

Figura 1. RM sagital potenciada en T1 de la ATM izquierda. A) imagen en boca cerrada donde se aprecia el disco articular (oscuro) colocado en posición anterior por delante del eje mayor del cóndilo mandibular. B) en máxima apertura oral se evidencia que el disco no se reduce y permanece deformado por delante del cóndilo.

Figure 1. Sagittal T1 weighted MR image of left TMJ. A) image in closed mouth position showing the articular disc (dark) in an anterior position in front of the major axis of the mandibular condyle. B) maximum mouth opening position showing how the disc is not reduced and how it remains deformed in front of the condyle. in closed mouth and maximum open mouth positions. This showed anteromedial disc displacement that was not recaptured by the left TMJ on mouth opening, (Fig. 1) and a disc that was stuck or anchored in the right TMJ (Fig. 2). The T2 weighted sequences showed intra-articular effusion of the left TMJ. The final diagnosis was of disc luxation without reduction of left TMJ, and anchored disc of right TMJ.

With this diagnosis arthroscopic surgery was suggested for diagnosing and treating this pathology. She was operated on under general anesthesia with nasotracheal intubation and prepared according to the normal protocol. An arthroscope similar to the Dyonics HD 900 (Smith \& Nephew Inc., TARMA S.A.) was used with a $1.9 \mathrm{~mm}$ diameter lens and with an angle of vision of $30^{\circ}$ and a xenon light source. The operation was recorded on a U-matic video (Sony v05630) and images were captured and printed using a video printer (Sony Color Video Printer, Mavigraph UP. banda posterior (Fig. 3). Se objetivó la correcta posición del disco articular en boca abierta, con un roofing del 100\% (porcentaje de cóndilo mandibular que está recubierto de disco articular); éste hecho puede comprobarse observando en boca abierta que la unión del disco articular con la banda posterior se encuentra por detrás del eje mayor de la eminencia temporal de la ATM (Fig. 3). Al progresar anteriormente se encontró un área eritematosa bien definida de unos $10 \mathrm{~mm}$ de diámetro que afectaba al tejido sinovial que recubría la porción media de la eminencia (Fig. 4). Al explorar la zona medial se observó una adherencia fibrosa lineal que unía el disco articular en su parte media con dicho área de la eminencia (Fig. 5), adherencia que fue cortada mediante lisis directa con la punta del artroscopio (Fig. 6). Tras explorar el receso anterior y no encontrar patología alguna así como comprobar la correcta movilidad discal dentro de la articulación, se realizó un profuso lavado intraarticular con $500 \mathrm{ml}$ de suero Ringer lactato y se finalizó la artroscopia derecha. La artroscopia en la ATM izquierda evidenció un desplazamiento discal anterior sin reducción con un roofing del 30\%, y una sinovitis grado III con gruesas adherencias en el receso anterior articular; se llevó a cabo triangula-
3000P). The right TMJ and the upper right joint space were approached first using a standard posterolateral portal and an intermediate portal for serum outflow. The examination was carried out by means of the usual protocol, posterior to anterior, lateral to medial, and initially a nearly normal joint was observed with no synovitis and with little inflammation of the posterior band (Fig. 3). The correct position of the disc was observed in the open mouth position together with 100\% roofing (the percentage of the mandibular condyle that is covered by the disc). This can be verified in the open mouth position by observing if the union between the disc and the posterior band is behind the major axis of the TMJ eminence (Fig. 3). On progressing forward, an erythematous area was encountered that was well-defined and that measured $10 \mathrm{~mm}$ in diameter. It was affecting the synovial tissue that was covering the middle part of the eminence (Fig. 4). An examination of the medial portion revealed a fibrous adherence in a line that joined the middle of the articular disc with this area of the eminence (Fig. 5). This was cut 
ción por vía anterolateral, resección de dichas adherencias, miotomía anterior con bisturí monopolar e infiltración subsinovial de la banda posterior con corticoides previa coagulación con bisturí eléctrico bipolar.

Se instauró un protocolo de fisioterapia domiciliaria y su evolución fue satisfactoria con unos movimientos a los 6 meses de $40 \mathrm{~mm}$ en máxima apertura oral y laterotrusiones de $5 \mathrm{~mm}$ hacia ambos lados, habiendo disminuido el dolor.

\section{Discusión}

La posible patogénesis del SDA ha sido definida por algunos autores como «una brusca adherencia del disco articular a la fosa que podría ser causada por una alteración de la lubricación normal de la articulación como resultado de una sobrecarga articular intermitente que produciría una activación secundaria de radicales oxidativos libres (estrés oxidativo) y una degradación del ácido hialurónico». El resultado final sería un incremento de la fricción entre el disco y los componentes óseos de la ATM lo que llevaría a un desplazamiento discal secundario y posteriormente a un proceso degenerativo articular (osteoartrosis). ${ }^{2-4,6,7}$ Inicialmente se pensó que el disco se anclaba a la fosa por un
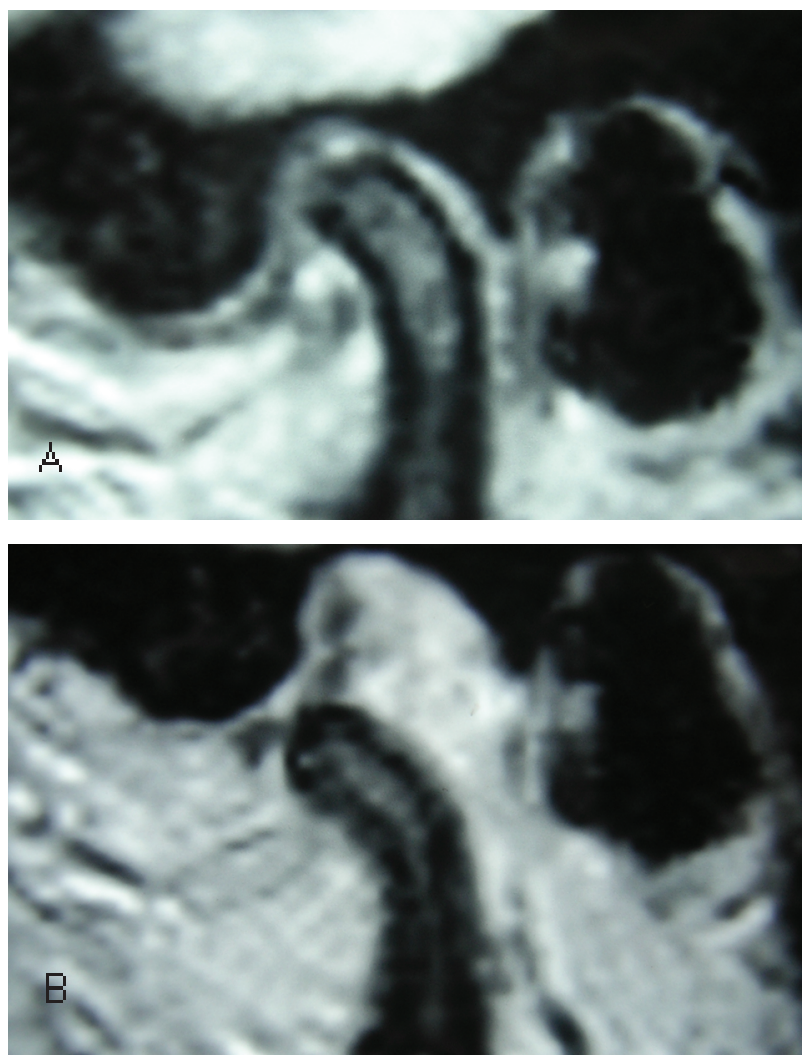

Figura 2. RM sagital potenciada en T1 de la ATM derecha. A) imagen en boca cerrada donde se aprecia el disco articular (oscuro) colocado en una posición adecuada respecto al cóndilo mandibular. B) en máxima apertura oral se observa que el disco no se moviliza ni acompaña al cóndilo, estando «anclado» a la eminencia articular.

Figure 2. Sagittal T1 weighted MR image of right TMJ. A) image in closed mouth position showing articular disc (dark) in its proper position with regard to the mandibular condyle. B) maximum mouth opening position showing how the disc does not slide or accompany the condyle due it being "anchored» to the articular eminence. mecanismo de presión negativa, ${ }^{8}$ aunque hoy en día se ha demostrado que hay una alteración bioquímica que provoca la adhesión de las superficies. ${ }^{2}$ De este modo, el disco articular, que en su porción central fibrocartilaginosa tiene una forma levemente bicóncava adaptándose a las superficies óseas entre las cuales se interpone (cóndilo y fosa), se adheriría a la fosa glenoidea como una «ventosa» quedando entonces inmóvil durante los movimientos de apertura y cierre bucal. Según diversos estudios, la mayoría de las veces el disco permanece en una posición adecuada, aunque también puede quedarse anclado en una posición anterior. ${ }^{5}$ Es por ello, que estos mismos estudios demuestran que en la mayor parte de las ocasiones de SDA el disco sigue manteniendo una morfología normal, tal y como podía observarse en el presente caso (Fig. 2).

Clínicamente, el SDA se comporta como un desplazamiento discal anterior sin reducción en la apertura de la boca (closed lock). Por ello, para diferenciarlos se hace necesaria alguna prueba de imagen, siendo hoy el día la RM la más sensible y específica.

En la mayoría de las ocasiones en el SDA el disco se adhiere a la fosa-eminencia articular de una manera tan potente, que los tra- by means of direct lysis with the point of the arthroscope (Fig. 6). As the examination of the anterior recess revealed no pathological findings, and as the correct movement of the disc in the joint was verified, extensive intra-articular lavage was carried out with $500 \mathrm{ml}$ of Ringer's lactate solution, and the right arthroscopy was completed. The arthroscopy of the left $T M J$ revealed an anterior displacement of the disc without reduction, roofing of $30 \%$, and grade III synovitis with thick adhesions in the anterior joint recess. Anterolateral triangulation was carried out, the adhesions were resected, an anterior myotomy was performed with a monopolar knife and the posterior band was infiltrated with subsynovial injections with corticoids following coagulation with an electric bipolar bistoury.

A home-based physiotherapy protocol was established and the patient evolved satisfactorily. At 6 months she had a maximal mouth opening of $40 \mathrm{~mm}$ and laterotrusion of $5 \mathrm{~mm}$ to both sides, and the pain had diminished.

\section{Discussion}

Some authors have defined the possible pathogenesis of $A D P$ as a sudden adhesion of the articular disc to the fossa that could be caused by changes in the normal lubrication of the joint as a result of intermittent overloading leading to free oxygen radicals (oxidative stress) and a degradation of hyaluronic acid. The end result would be an increase in the friction between the disc and the bone components of the TMJ leading to secondary disc displacement, and later to a degenerative process of the joints (osteoarthrosis). 2-4,6,7 Initially it was thought that the disc was anchored to the fossa by a negative pressure mechanism ${ }^{8}$ although it has now been demonstrated that there is a biochemical change leading to the adhesion of the surfaces. ${ }^{2}$ In this sense, the articular disc, which is slightly concave in the central fibro- 
tamientos conservadores convencionales (relajantes musculares, férulas oclusales, etc.) son incapaces de solucionar el problema. Por ello, diversos autores proponen actualmente la cirugía como el tratamiento de elección.6,9 Dentro de las alternativas quirúrgicas las técnicas mínimamente invasivas parecen ser hoy en día los métodos de elección. La artrocentesis es una técnica con muy escasa morbilidad, ampliamente empleada en la actualidad para el tratamiento de diversa patología articular y que se puede llevar a cabo bajo anestesia local. ${ }^{10}$ Consiste en la instilación de líquido (generalmente suero) dentro de la ATM y el posterior lavado de la articulación. En la mayoría de los casos esta técnica es suficiente para resolver el SDA. 6,10 Nitzan y Etsion, ${ }^{11}$ explican el mecanismo de acción de la artrocentesis en el SDA con la hipótesis de que inyectando fluido en el espacio articular superior, las superficies son separadas por hidro-disección, ayudando a la restauración de la motilidad del disco articular. Nosotros, al igual que otros autores, 12 pensamos que el aumento de la presión intra-articular también contribuiría al despegamiento del disco de la fosa; por ello, tal vez una simple instilación sin lavado articular sería suficiente en muchos casos para resolver el SDA, aunque el posterior lavado que se realiza en la artrocentesis ayudaría a limpiar las numerosas toxinas, proteínas y sustancias inflamatorias que se acumulan en la articulación. ${ }^{13}$

La artroscopia es una técnica altamente efectiva en la ATM y que además proporciona imágenes articulares, permitiendo actuar directamente sobre diferentes estructuras. Ha sido clásicamente empleada en diversas patologías, como el SDTM o la osteoartrosis. 9,14 También su empleo ha sido descrito para el tratamiento del SDA, aunque un reciente estudio de Sanromán compara la artroscopia frente a la artrocentesis sin encontrar diferencias significativas entre estas técnicas, siendo ambas igual de efectivas para tratar el SDA. ${ }^{6}$ Este mismo autor describe los hallazgos artroscópicos encontrados en las ATMs con SDA: en la mayoría de los casos el roofing se encontraba entre el $75 \%$ y el $100 \%$ como en el caso que nosotros presentamos, la sinovitis de la banda

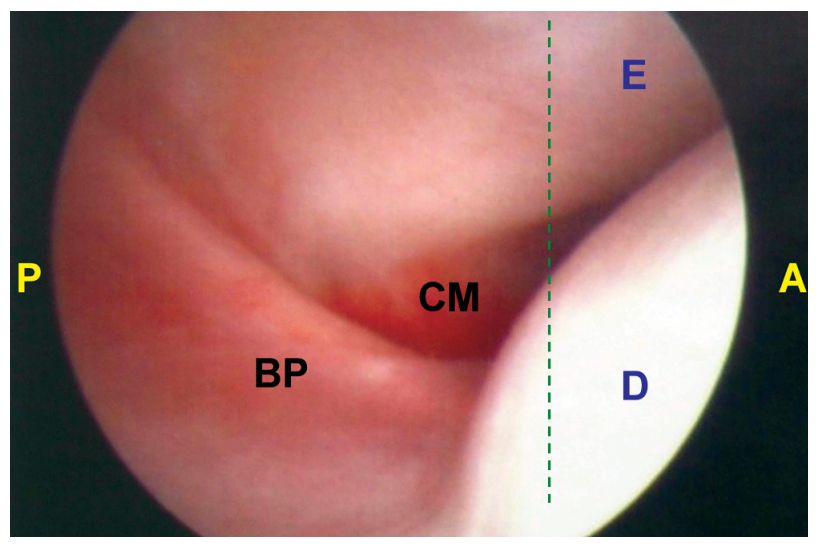

Figura 3. Imagen artroscópica del receso posterior del compartimento superior de la ATM derecha. Se puede observar que el disco articular (D) se encuentra correctamente posicionado respecto a la eminencia articular (E), con un roofing del 100\% (unión del disco articular y la banda posterior (BP) por detrás de la línea media de la eminencia ( $\mathrm{P}=$ posterior; $\mathrm{A}=$ anterior; $\mathrm{CM}=$ cápsula medial). Figure 3. Arthroscopic image of the posterior recess of the upper compartment of right TMJ. The articular disc (D) appears positioned correctly with regard to the joint eminence (E) with 100\% roofing (union of the articular disc with the posterior band $(B P)$ behind the midline of the eminence ( $P=$ posterior, $A=$ anterior, $C M=$ medial capsule).

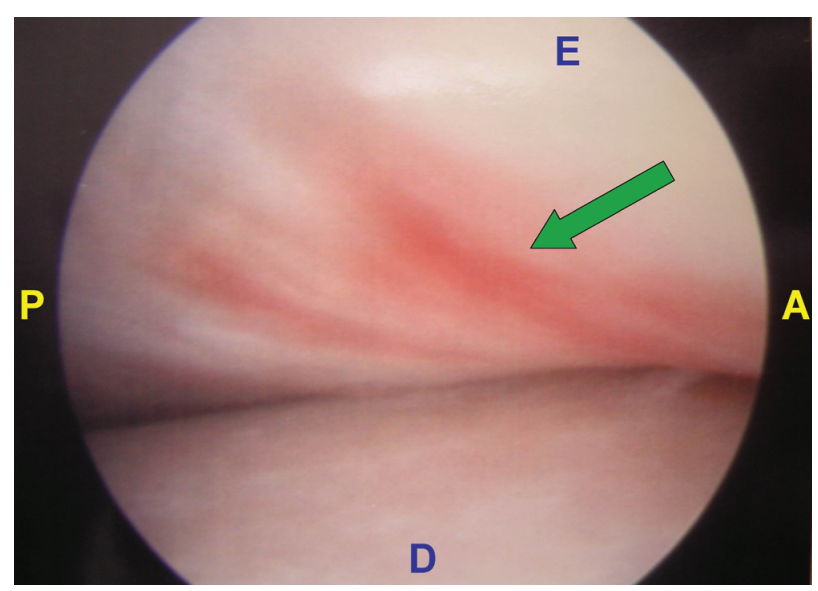

Figura 4. Imagen artroscópica de la porción intermedia del espacio articular superior. Se aprecia una zona eritematosa (flecha) de unos $10 \mathrm{~mm}^{2}$ en el tejido sinovial que recubre la porción media de la eminencia temporal de la ATM. La hipótesis es que esta lesión ha sido producida por el despegamiento del disco al introducir el artroscopio y hacer el lavado articular $(\mathrm{P}=$ posterior; $\mathrm{A}=$ anterior; $\mathrm{D}=$ disco; $\mathrm{E}=$ eminencia articular).

Figure 4. Arthroscopic image of intermediate portion of the superior joint space. An erythematous area (arrow) measuring $10 \mathrm{~mm}^{2}$ in the synovial tissue covering the medial portion of the temporal eminence of the TMJ can be appreciated. The hypothesis is that the lesion has been produced by the disc being released when the arthroscope was introduced to carry out joint lavage ( $P=$ posterior; $A=$ anterior; $D=$ disc; $E=$ joint eminence) cartilaginous part, adapts to the bone surfaces in which it is placed (condyle and fossa). It adheres to the glenoid fossa as if it were a suction cup and it therefore remains static during mouth opening and closing. According to various studies the disc will, on most occasions, remain in its proper position although it may sometimes be anchored in an anterior position. ${ }^{5}$ These same studies show that this is the reason why the disc maintains a normal morphology in most ADP cases, as can be observed in the present case (Fig. 2).

Clinically ADP appears as an anterior disc displacement without closed lock. Therefore, for differentiation purposes imaging studies have to be carried out, with MR imaging currently having the most sensitivity and specificity.

In most ADP cases, the disc will adhere to the fossa-eminence of the joint so strongly that conventional conservative treatment (muscle relaxants, occlusal splints...) is unable to solve the problem. As a result of this, many authors propose surgery as the treatment of choice. 6,9 Within the surgical alternatives, minimally invasive techniques seem to be the methods of choice. Arthrocentesis is a technique with very little morbidity that is widely used today for the treatment of various pathologies of the joint, and it can be carried out under local anesthesia. ${ }^{10}$ It consists in instilling liquid (generally saline) into the TMJ and the posterior lavage of the joint. On most occasions this is enough to resolve ADP. 6,10 Nitzan and Etsion ${ }^{11}$ explained the mechanism with which arthrocentesis acts on ADP. Their hypothesis was that by injecting fluid into the superior articular space, the surfaces 
posterior fue el hallazgo más común, aunque en el presente caso no existía, $y$ las adherencias fibrosas eran comunes. ${ }^{6}$ Respecto a las adherencias cabe destacar que es un hallazgo relativamente frecuente en la patología articular, aunque la mayoría aparecen en los recesos anterior y medial de la ATM. ${ }^{15}$ De hecho, en nuestra experiencia personal en más de 320 artroscopias nunca habíamos encontrado una adherencia localizada entre la porción media del disco articular y la fosa, sin que existiera una sinovitis asociada (Figs. 5 y 6). Pero posiblemente el hallazgo más sorprendente encontrado en el presente caso sea ese área eritematosa localizada en la zona media de la fosa-eminencia glenoidea, presentando la sinovial que la rodea un aspecto normal (Fig. 4). Nuestra hipótesis es que el despegamiento del disco adherido, realizado inmediatamente antes al introducir la cánula en el receso posterior e instilar suero, habría provocado esa zona eritematosa por una subfusión hemorrágica al despegar ambos tejidos, de una manera similar a la marca que deja una ventosa en un cristal cuando es despegada. Las adherencias en este caso podrían deberse a la larga evolución de SDA, ya que se ha demostrado que éstas son más frecuentes en casos de larga evolución. ${ }^{15}$

Posiblemente sean necesarios futuros estudios correlacionando los hallazgos artroscópicos en el SDA, con el fin de comprobar si lo encontrado en el presente caso es específico de esta patología.

\section{Bibliografía}

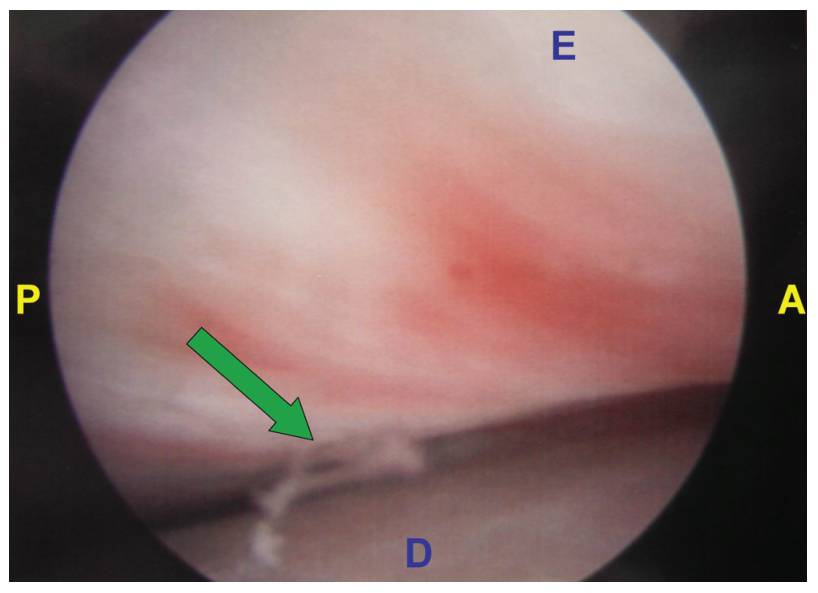

Figura 5. Al avanzar hacia delante y hacia medial se aprecia una pequeña adherencia (flecha) colocada entre la porción media de disco articular y la eminencia. Estas adherencias son extremadamente raras en esta localización. sion can be appreciated (arrow) between the middle portion of the articular disc and the eminence. These adherences are extremely rare in this location.

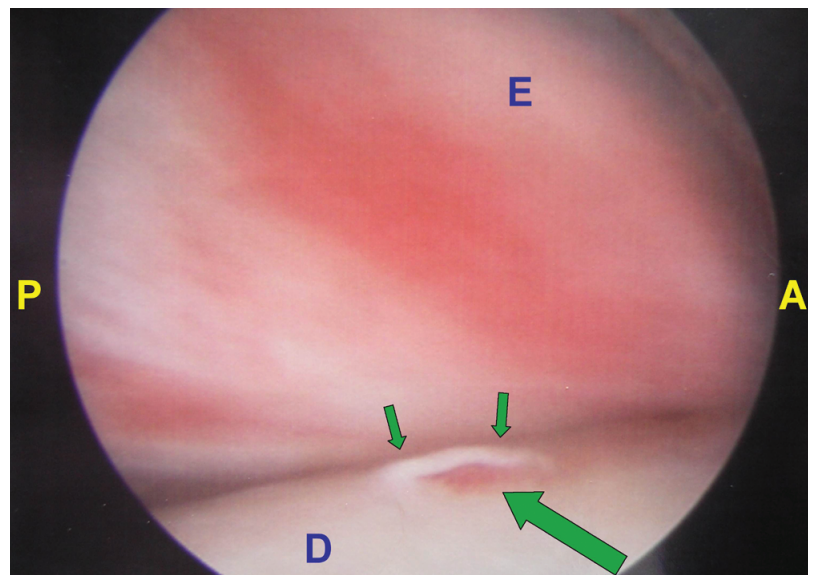

Figura 6. Tras una maniobra de lisis directa con el artroscopio se rompe la adherencia (flechas pequeñas) observándose una pequeña zona eritematosa remanente en la sinovial del disco articular (flecha grande).

Figure 6. After carrying out direct lysis with the arthroscope, the adhesion is broken away (small arrows). The small erythematous area that remains can be observed in the synovial membrane of the articular disc (large arrow).
Figure 5. On progressing forwards towards the middle a small adhe-

are separated by means of hydro-dissection, thus helping to restore motility of the articular disc. We believe, as do other authors, ${ }^{12}$ that the increase in intra-articular pressure could also lead to the disc being released from the fossa; thus, simple instillation without joint lavage could be enough to resolve many cases of $A D P$, although lavage carried out later on during the arthrocentesis would help to clean away all the toxins, proteins and inflammatory substances that accumulate in the joint. ${ }^{13}$

Arthroscopy is a highly effective technique for dealing with ADP that also provides images of the joints, allowing work to be carried out directly on the different structures. It has been used traditionally in different pathologies such as TMDs or osteoarthrosis.9,14 Its use has also been described for treating $A D P$, although a recent study by Sanroman compares arthroscopy with arthrocentesis. No significant differences were found between these techniques, and both were equally effective for treating ADP. ${ }^{6} \mathrm{He}$ describes the arthroscopic findings in the TMJ with ADP, reporting that the rate of roofing that in most cases was between $75 \%$ and $100 \%$, as in the case we present. Synovitis of the poste-

1. Nitzan DW. An alternative explanation for the genesis of closed lock symptoms in the internal derangement process. J Oral Maxillofac Surg 1991;49:810-5.

2. Nitzan DW, Marmary Y. The «anchored disc phenomenon»: A proposed etiology for sudden-onset, severe, and persistent closed lock of the temporomandibular joint. J Oral Maxillofac Surg 1997;55:797-802.

3. Nitzan DW. The process of lubrication impairment and its involvement in temporomandibular joint disc displacement: A theoretical concept. / Oral Maxillofac Surg 2001; 59:36-45.

4. Nitzan DW, Goldfarb A, Gati I, Kohen R. Changes in the reducing power of synovial fluid from temporomandibular joints with «anchored disc phenomenon». J Oral Maxillofac Surg 2002;60:735-40. rior band was the most common finding, although in the present case there was none, and fibrous adhesions were common. ${ }^{6}$ With regard to adhesions, it should be pointed out that it is a relatively frequent finding in joint pathology, although most appear in the anterior and medial recesses of the TMJ..$^{15}$ In fact, in our personal experience of more than 320 arthroscopies, we have never found an adhesion that was situated in the middle portion of the articular disc and fossa without associated synovitis (Fig. 5 and 6). But, possibly the most surprising discovery in this case was the ery- 
5. Sanroman JF. Closed lock (MRI fixed disc): A comparison of artrocentesis and arthroscopy. Int J Oral Maxillofac Surg 2004;33:344-8.

6. Nitzan DW, Mahler Y, Simkin A. Intra-articular pressure measurements in patients with suddenly developing severely limited mouth opening. I Oral Maxillofac Surg 1992;50:1038-43.

7. Milam SB, Zardeneta G, Schmitz JP. Oxidative stress and degenerative temporomandibular joint disease: A proposed hypothesis. J Oral Maxillofac Surg 1998; $56: 214-23$.

8. Nitzan DW, Dolwick MF. An alternative explanation for the genesis of closedlock symptoms in the internal derangement process. J Oral Maxillofac Surg 1991; 49:810-5.

9. Dimitroulis $\mathrm{G}$. The role of surgery in the management of disorders of the temporomandibular joint. A critical review of the literature. Part 2. Int J Oral MaxiIlofac Surg 2005;34:231-7.

10. Martin-Granizo R. Artrocentesis de la articulación témporomandibular: Indicaciones, técnica quirúrgica y resultados. Rev Col Odontoestomatol Esp- RCOE 2001;6:375-83.

11. Nitzan DW, Etsion I. Adhesive force: The underlying cause of the disc anchorage to the fossa and/or eminence in the temporomandibular joint-a new concept. Int J Oral Maxillofac Surg 2002;31:94-9.

12. Yura S, Totsuka Y. Relationship between effectiveness of arthrocentesis under sufficient pressure and conditions of the temporomandibular joint. J Oral Maxillofac Surg 2005;63:225-8.

13. Zardeneta G, Milam SB, Schmitz JP. Elution of proteins by continuous temporomandibular joint arthrocentesis. J Oral Maxillofac Surg 1997;55:709-16.

14. Davis CL, Kaminishi RM, Marshall MW. Arthroscopic surgery for treatment of closed lock. J Oral Maxillofac Surg 1991;49:704-7.

15. Kaminishi RM, Davis CL. Temporomandibular joint arthroscopic observations of the superior space adhesions. Oral Maxillofac Surg Clin North Am 1989;1:103-9. thematous area found in the middle area of the glenoid fossaeminence, and the normal appearance of the synovial membrane surrounding it (Fig. 4). Our hypothesis is that the releasing of the adhered disc, which was carried out immediately before introducing the cannula into the posterior recess and instilling saline, could have produced the erythematous area as a result of a hemorrhagic subfusion as both tissues were released, leaving a mark similar to that left by a suction cup in a window when it is unstuck. The adhesions in this case could be due to the lengthy evolution of $A D P$, as it has been demonstrated that these are more frequent in cases that have been developing for longer. ${ }^{15}$

Future studies may possibly be necessary that correlate arthroscopic findings in ADP in order to ascertain whether what was found in our case is specific to this pathology. 